Research Article

\title{
Clinical Characteristic of Adult Patients with Dengue Hemorrhagic Fever at Prof. Dr. Sulianti Saroso Sunter Infectious Hospital 2018
}

\author{
Ghina Rasyidah ${ }^{1}$, Adinta Anandani ${ }^{2}$ \\ 1) Medical Study Program, Faculty of Medicine and Health, Universitas Muhammadiyah Jakarta \\ 2) Department of Microbiology and Parasitology, Faculty of Medicine and Health, Universitas Muhammadiyah Jakarta \\ *rnaginaraa@gmail.com
}

\begin{abstract}
Background: Dengue is a viral disease transmitted by mosquito to humans and becomes a problem for the health of Indonesian people. Dengue Hemorrhagic Fever occurs due to several epidemiological factors. The purpose of this study is to determine the clinical characteristics of adult patients with Dengue Hemorrhagic Fever at Prof. dr. Sulianti Saroso Sunter Infectious Hospital 2018. Method: This Study was an observational descriptive study by taking medical record samples in 49 adult patients Dengue Hemorrhagic Fever in 2018. Results: From the 49 cases of Dengue Haemorrhagic Fever, the highest fender category was male $(65,3 \%)$, occurred in the $18-25$ year age category $(38,8 \%)$, and the average patient worked as a Private Employee $(55,1 \%)$. Most patients were hospitalized for the less than 7 days $(83,7 \%)$. Clinical manifestations were fever $(95,9 \%)$, nausea $(85,7 \%)$ and headache $(71,4 \%)$. Physical examination found was fever (100\%) and hepatomegaly $(12,2 \%)$. Laboratory tests showed normal hematocrit values $(71,4 \%)$, thrombocytopenia values $(87,8 \%)$, normal leukocyte values $(49 \%)$, positive IgG serology tests $(83,7 \%)$, IgM serology tests $(71,4 \%)$, Positive IgM and IgG Serology test $(69,3 \%)$, and NS1 Serology test (2\%). Management provided is the administration of intravenous infus fluid drops (100\%), PPI (87,8\%), H2 Antagonist (4,1\%), and Antipiretik (83,7\%). The outcome patient is recovered and no complications were found. Conclusion: Dengue Hemorrhagic fever occurs in the age range of 18-25 years with dominant clinical characteristic of fever and thrombocytopenia. And, the most given treatment is Intravena Fluid therapy.
\end{abstract}

Keywords: Dengue Hemorrhagic Fever, Clinical Characteristic, Adult Patients.

\section{INTRODUCTION}

Dengue virus are transmitted by mosquito to humans with a 30-fold increase in global incidents during the last five changes. According to WHO, around 50100 million new infections are estimated to occur each year in more than 100 endemic countries, with a steady increase in the number of countries reported by this disease. From 1968 to 2009, WHO noted that Indonesia was the country with the highest Dengue Hemorrhagic Fever (DHF) cases in Southeast Asia (1).

DHF cases in Indonesia In 2017, the number of DHF cases increased by 68,407 cases with 493 people died and IR 26.12 per 100,000 population compared to 2016 with 204,171 cases and IR 78.85 per 100,000 population reporting risk cases at 2017 (2). 
DHF is still one of the health problems in the community in Indonesia in the last 47 years. This disease is caused by dengue virus which has the genus Flavivirus and Flaviviridae family, has 4 serotypes namely DEN 1, DEN 2, DEN 3, etc. DEN 4. The increase in DHF can be caused by several factors such as climate change, population density, population mobility height, urban development, population distribution and other epidemiological factors (3).

Besides being caused by several epidemiological factors, the spread of this disease according to some results of previous studies, it was found that Dengue Hemorrhagic Fever more attacking at the age of children compared to adult age, but when viewed from the sex there is no significant difference in patients Dengue Hemorrhagic Fever. So, from this description, the researchers wanted to find out how the characteristics of adult patients who have Dengue Hemorrhagic Fever.

This research was conducted at Prof. dr. Sulianti Saroso Infectious Hospital, located in Sunter. This hospital is a type A hospital and is a referral hospital and center for infectious disease studies in Indonesia.

\section{METHODS}

This research use descriptive observational with cross-sectional design. The data taken is secondary data from the medical records of adult patients in 2018. The population used is all adult patients diagnosed with Dengue Fever at Prof. dr. Sulianti Saroso Infectious Hospital, located in Sunter, North Jakarta. By using the Total Sampling technique, a sample of 49 adult patients was diagnosed with enforcement through history taking, physical examination, and supporting examination.

Preparations for the study were conducted from October to December 2019. Samples would not be included if adult DHF patients had accompanying illnesses and medical record data were incomplete.

Variables obtained from gender, age, occupation, length of stay, clinical symptoms, physical examination, blood laboratory tests and serology tests, complications, and outcomes. After data collection, the data will be processed using the Statistical Package for the Social Sciences (SPSS) program.

The research ethics permit was obtained from the Health Research Ethics Committee of the Faculty of Medicine and Health, Muhammadiyah University, Jakarta. The ethics approval number is 098 / PE / KE / FKK-UMJ / X / 2019

\section{RESULT}

The results of 49 adult patients with inclusion and exclusion criteria. Patients treated at Prof. dr. Sulianti Saroso Sunter Infectious Hospital in 2018.

Table 1. Frequency Distribution by Gender

\begin{tabular}{ccc}
\hline Gender & Frequency & Percentage (\%) \\
\hline Male & 32 & 65,3 \\
Female & 17 & 34,7 \\
\hline Total & 49 & 100,0 \\
\hline
\end{tabular}

Based on Table 1, the gender most affected by dengue fever were male, 32 patients $(65.3 \%)$, more than women. The average adult patients affected by DHF in the age category 18-25 years as many as 19 patients $(38.8 \%)$. The age range is shown in Table 2. 
Table 2. Frequency Distribution by Age

\begin{tabular}{ccc}
\hline Age & Frequency & Percentage (\%) \\
\hline $18-25$ & 19 & 38,8 \\
$26-35$ & 8 & 16,3 \\
$36-45$ & 10 & 20,4 \\
$46-55$ & 6 & 12,2 \\
$>56$ & 6 & 12,2 \\
\hline Total & 49 & 100,0 \\
\hline
\end{tabular}

Table 3. Frequency Distribution by Occupation

\begin{tabular}{ccc}
\hline Occupation & Frequency & Percentage $(\%)$ \\
\hline Private Employee & 27 & 55,1 \\
Student & 11 & 22,4 \\
Unemployed & 7 & 14,3 \\
Civil Servant & 3 & 6,1 \\
Entreprenuer & 1 & 2 \\
\hline Total & 49 & 100,0 \\
\hline
\end{tabular}

Tabel 4. Frequency Distribution by Length of

\begin{tabular}{ccc}
\multicolumn{2}{c}{ Stay } & \\
\hline $\begin{array}{c}\text { Length Of } \\
\text { Stay }\end{array}$ & Frequency & Percentage (\%) \\
\hline$<7$ day & 41 & 83,7 \\
$>7$ day & 8 & 16,3 \\
\hline Total & 49 & 100 \\
\hline
\end{tabular}

Table 3 shows the 27 patients (55.1\%) who were most exposed to DHF worked as Private Employee. Based on Table 4, the average length of stay of adult patients diagnosed with DHF at Prof. dr. Sulianti Saroso Sunter Infectious Hospital in 2018 was $<7$ days in 41 patients (83.7\%). Table 5 shows the most common clinical symptoms were Fever in 47 patients $(95.9 \%)$, Nausea in 42 patients (85.7\%), Headache in 35 patients $(71.4 \%)$, Vomiting in 30 patients $(61.2 \%)$, and Abdominal Pain in 11 patients (22.4\%).
Tabel 5. Frequency Distribution by Clinical Symptoms

\begin{tabular}{lcc}
\hline \multicolumn{1}{c}{$\begin{array}{c}\text { Clinical } \\
\text { Symptoms }\end{array}$} & Frequency & Percentage (\%) \\
\hline Fever & 47 & 95,9 \\
Nausea & 42 & 85,7 \\
Headache & 35 & 71,4 \\
Vomiting & 30 & 61,2 \\
Abdominal Pain & 11 & 22,4 \\
Myalgia & 7 & 14,3 \\
Athralgia & 7 & 14,3 \\
Diarrhea & 6 & 12,2 \\
Hematemesis & 4 & 8,2 \\
Gum Bleeding & 4 & 8,2 \\
Epistaxis & 3 & 6,1 \\
Melena & 2 & 4,1 \\
Petechiae & 1 & 2,0 \\
\hline
\end{tabular}

Tabel 6. Frequency Distribution by Phisical Examination

\begin{tabular}{lcc}
\hline $\begin{array}{c}\text { Physical } \\
\text { Examination }\end{array}$ & Frequency & Percentage (\%) \\
\hline Fever & 49 & 100,0 \\
Hepatomegaly & 6 & 12,2 \\
\hline
\end{tabular}

Based on Table 6, the most common physical examination found in adult DHF patients is Fever in 49 patients $(100 \%)$ and there was hepatomegaly in 6 patients (12,2\%). Based on Table 7, normal hematocrit values were higher in 35 patients $(71.4 \%)$, thrombocytopenia occurred in 43 patients $(87.8 \%)$, and normal leukocyte values were higher in 24 patients $(49 \%)$. 
Table 7. Frequency Distribution by Blood Test

\begin{tabular}{llcc}
\hline Blood Test & \multicolumn{1}{c}{ Values } & Frequency & $\begin{array}{c}\text { Percentage } \\
(\%)\end{array}$ \\
\hline Hematocrit & Normal & 35 & 71,4 \\
& Low & 14 & 28,6 \\
& High & 0 & 0 \\
Platelet & Normal & 6 & 12,2 \\
& Thrombo- & 43 & 87,8 \\
& cytopenia & & \\
& Thrombocy- & 0 & 0 \\
& tosis & & \\
Leukocyte & Normal & 24 & 49,0 \\
& Leukopenia & 19 & 38,8 \\
& Leukocyto-sis & 6 & 12,2 \\
\hline
\end{tabular}

Table 8. Frequency Distribution by Serology Test

\begin{tabular}{lccc}
\hline \multicolumn{1}{c}{ Serology Test } & Values & Frequency & $\begin{array}{c}\text { Percentage } \\
(\%)\end{array}$ \\
\hline $\begin{array}{l}\text { IgG Serology } \\
\text { Test }\end{array}$ & Positive & 41 & 83.7 \\
$\begin{array}{l}\text { IgM Serology } \\
\text { Test }\end{array}$ & Positive & 35 & 71.4 \\
$\begin{array}{l}\text { IgG and IgM } \\
\text { Serology Test }\end{array}$ & Positive & 34 & 69,3 \\
$\begin{array}{l}\text { NS1Serology } \\
\text { Test }\end{array}$ & Positive & 1 & 2 \\
\hline
\end{tabular}

Table 9. Frequency Distribution by Management Patients with DHF

\begin{tabular}{lcc}
\hline \multicolumn{1}{c}{ Management } & Frequency & Percentage (\%) \\
\hline Infus Intravena & & \\
Fluid Drops & 49 & 100,0 \\
(IVFD) & & \\
Proton Pump & 43 & 87,8 \\
Inhibitor & 41 & 83,7 \\
Anti Piretik & 2 & 4,1 \\
H2 Antagonis & 2 & \\
\hline
\end{tabular}

The most test with positive frequency scores is the IgG Serology Test found in 41 people $(83.7 \%)$ shows in Table 8. Based on Table 9, shows that the most frequent treatment given to patients is intravenous fluid drops in 49 patients $(100 \%)$.

Table 10 shows in research there are no complication in 49 patients with Dengue Hemorrhagic Fever (100\%). Based on Table 11, shows that the outcome is good in 48 patients (100\%) Dengue Hemorrhagic Fever).

Table 10. Frequency Distribution by Complication

\begin{tabular}{ccc}
\hline Complication & Frequency & Percentage (\%) \\
\hline No & 100 & 100,0 \\
\hline Total & 49 & 100.0 \\
\hline
\end{tabular}

Tabel 11. Frequency Distribution by Outcome

\begin{tabular}{lcc}
\hline \multicolumn{1}{c}{ Outcome } & Frequency & Percentage (\%) \\
\hline Recover & 48 & 98.0 \\
Death & 1 & 2.0 \\
\hline \multicolumn{1}{c}{ Total } & 49 & 100.0 \\
\hline
\end{tabular}

\section{DISCUSSION}

The results of the study stated that the gender most affected by DHF were men. However, different results were obtained in previous studies which stated that there were no significant differences between men or women affected by this disease, but the difference in adult patients affected by DHF can be caused because men are more often outside the home compared to inside home so that mosquito bite activity is higher in males compared to females (4).

Adult patients affected by DHF at Prof. dr. Sulianti Saroso Sunter Infectious Hospital in 2018 more aged between 18-25 years, when compared with previous studies that the age that is often affected in adult patients with DHF is 39 years old. There is a considerable age difference, but that age is still included in the productive age (5).

Most of the patients work as private employees in 28 people $(57.1 \%)$, and the 
average length of stay of patients at Sulianti Saroso Sunter Infectious Hospital in 2018 is $<7$ days, according to previous research which states that the average length of stay at Dengue Hemorrhagic Fever patients are under 7 days (6).

Observation of temperature was carried out since the patient came to the hospital, then fever symptoms were found in 49 patients diagnosed with DHF. This fever will go up continuously on day 1 to day 3 , then will experience a critical phase where the fever will begin to decrease on day 4 to day 6 , then it will return to normal the next day. Fever occurs due to a healing reaction (7).

When the dengue virus enters the body and starts replicating, the virus will be captured by macrophages then phagocytosed, activating Helper $\mathrm{T}$ cells, Helper $\mathrm{T}$ cells then activating $\mathrm{B}$ lymphocyte B cells. B lymphocyte cells will release antibodies that play a role in various processes that release various mediators like TNF alpha, IL-1, IL-6, and others. These cytokines will stimulate the hypothalamus and cause an increase in prostaglandin secretion, will cause changes in the set point in the hypothalamus and an increase in body temperature (8) .

Another symptom that is prevalent in DHF patients is nausea and vomiting, based on data taken through medical records, nausea of 42 people $(85.7 \%)$ while patients who experienced vomiting of $30(61.2 \%)$, according to previous research which states that almost all patients feel nausea when exposed to DHF (9).

The symptoms of headaches and abdominal pain are also the most common symptoms found in adult DHF patients at Prof. dr. Sulianti Saroso Sunter Infectious Hospital in 2018. Symptoms of headache were found in 35 patients $(71.4 \%)$, while symptoms of abdominal pain were found in 11 patients $(22.4 \%)$. According to previous studies, abdominal pain is felt more in adults than in young children (10).

Physical examination to help make the diagnosis in DHF patients. In this study, it was found that the most physical examination obtained in patients was fever in 49 people $(100 \%)$ and hepatomegaly was also found during physical examination in 6 patients $(12.2 \%)$.

In addition to physical examinations, supporting examinations are also carried out by conducting routine blood tests and serological tests on DHF patients. The highest value obtained was the normal hematocrit value in 35 patients $(71.4 \%)$. To make the diagnosis found at least one sign of plasma leakage, one of which is found an increase in hematocrit> $20 \%$. However, in this study no increase was found in haematocrit (11).

Then, obtained the highest value is the normal leukocyte value in 24 patients $(49 \%)$. If, the value of leukocytes decreases or leukocytosis occurs, the patient will experience a shock phase. In this research result, there were 6 patients with leukocytosis $(12.2 \%)$, but none of the patients experienced shock. On platelet test found thrombocytopenia in 43 patients $(87.8 \%)$. In accordance with the criteria to determine the diagnosis of Dengue Hemorrhagic Fever that is thrombocytopenia $<100,000 / \mathrm{IU}$ or platelet values are below normal (11).

IgG serology test, positive values were obtained in 41 patients $(83.7 \%), \operatorname{IgM}$ serology tests obtained positive values in 35 patients $(71.4 \%), \operatorname{IgG}$ and $\operatorname{IgM}$ serology tests with positive values in 34 patients $(69.3 \%)$ and NS1 serological test found positive values in 1 patient $(2 \%)$. To make 
the diagnosis in patients with Dengue Hemorrhagic Fever, in addition to a blood laboratory test, a Rapid Diagnostic Test can also be performed. Included in the Rapid Diagnostic Test are the IgM Serology test, the IgG serology test, and the NS1 serology test. In Dengue Hemorrhagic Fever there are more secondary than primary infections. Secondary infection is when the IgM serological test $(+)$ and $\operatorname{IgG}$ serological test $(+)$ while the primary infection occurs during the IgM serological test (+) while the IgG serological test (-). Anti dengue IgM is the primary antibody in a person who is exposed to the dengue virus for the first time. And, the positive results obtained from the $\operatorname{IgG}$ serology test are to show the existence of recurrent infections or previous exposure to Dengue Hemorrhagic Fever (12).

The treatment given to DHF patients in this study, giving infusion or fluids is the most given treatment that is given to 49 patients $(100 \%)$. In general, for patients affected by Dengue Fever there is no specific therapy, but in accordance with the main principle that is supportive therapy, with adequate therapy, the mortality rate can be reduced to less than $1 \%$. So that the most important action in handling DHF cases is maintaining the volume of circulating fluid in the body (11).

Furthermore, the drug given to patients with Dengue Hemorrhagic fever is an antipyretic class of drugs. This drug was given to 41 patients $(83.7 \%)$ who experienced fever while hospitalized. In accordance with the management according to WHO 2015, patients who are exposed to Dengue Hemorrhagic Fever in addition to being given fluids are also given Antipyretics.
Proton Pump Inhibitor drug group was given to 43 patients $(87.8 \%)$ and patients were also given $\mathrm{H} 2$ Antagonist drug group with 2 patients $(4.1 \%)$ due to nausea and vomiting.

Based on data taken through medical records in adult patients with Dengue Hemorrhagic Fever at Prof. Sulianti Saroso Sunter Infectious Hospital in 2018, no complications were found in all patients. In contrast to previous studies, that there are complications in patients with DHF, which is a pleural effusion.

Based on a total of 49 patients affected by Dengue Hemorrhagic Fever taken at Prof. Sulianti Saroso Sunter Infectious Hospital In 2018, there were 48 patients (98\%) with a good Outcome, while 1 patient (2\%) with a outcome died. However, the patient died was not caused by Dengue Hemorrhagic Fever but was caused by other comorbidities, the accompanying illness that caused the death of the patient was sepsis shock caused by diphtheria.

\section{CONCLUSION}

Based on the results of the study, the highest fender category was male $(65,3 \%)$ as 32 people compared to female gender as 17 people. Patients affected by DHF on average aged 18-25 years, with an average length of stay $<7$ days. The most common clinical symptoms are fever, nausea, headache, vomiting and abdominal pain. Physical examination that is commonly found is fever and hepatomegaly.

For supporting examinations carried out namely blood tests and serological examinations. The dominant result obtained at blood tests is thrombocytopenia and the dominant result obtained on serological examination is the IgG serology test with positive results. The 
most common treatment given to patients is intravenous infusion fluid drops given to 49 patients. There are no complications were found when the patient was treated at Prof. dr. Sulianti Saroso Sunter Infectious Hospital in 2018. The outcome of patients with DHF is cured.

\section{ACKNOWLEDGMENT}

The authors would like to thank the Prof. dr. Sulianti Saroso Sunter Infectious Hospital for given permission to take a 49 samples and make this process run good. We would also like to thank the Universitas Muhammadiyah Jakarta and all friends who have helped and supported this research.

\section{CONFLICT OF INTEREST}

The authors state they have no conflict of interest, and no affiliation or connection to or with any entity or organization, which may raise a question of bias in discussion and conclusion of the manuscript.

\section{REFERENCE}

1. WHO. National Guidelines Clinical Management Dengue Fever. 2015.

2. Kementrian Kesehatan RI. InfoDatin Situas Demam Berdarah Dengue. 2018.

3. Kementrian Kesehatan RI. InfoDatin Kementerian Kesehatan RI. Kemenkes RI. 2016.

4. Suryani ET. Gambaran Kasus Demam Berdarah Dengue di Kota Blitar Tahun 2015-2017. J Berk Epidemiol. 2018;6(3):260-7.

5. Low JGH, Ong A, Tan LK, Chaterji S, Chow A, Lim WY, et al. The early clinical features of dengue in adults: Challenges for early clinical diagnosis. PLoS Negl Trop Dis. 2011;5(5).
6. Divy NPA, Sudarmaja IM, Swastika IK. Karakteristik Penderita Demam Berdarah Dengue (DBD) di RSUP Sanglah Bulan Juli - Desember Tahun 2014. 2018;7(7):1-7.

7. Mayasari R, Sitorus H, Salim M, Oktavia S, Supranelfy Y, Wurisastuti T. Karakteristik Pasien Demam Berdarah Dengue pada Instalasi Rawat Inap RSUD Kota Prabumulih Periode Januari-Mei 2016. Media Penelit dan Pengemb Kesehat. 2019;29(1):39-50.

8. Hall G. Buku Ajar Fisiologi Kedokteran. Jakarta: Elsevier; 2016.

9. Kurniawan M, Juffrie M, Rianto BUDR. Hubungan tanda dan gejala klinis terhadap kejadian syok pada pasien demam berdarah dengue (DBD) di RS PKU Muhammadiyah Gamping Daerah Istimewa Yogyakarta. Mutiara Med. 2015;15(1):1-6.

10. Annisa D, Hapsari M, Farhanah N. Perbedaan Profil Klinis Penyakit Demam Berdarah Dengue (DBD) Pada Anak dan Dewasa. J Kedokt Diponegoro. 2015;4(4):582-91.

11. Setiati S, Alwi I, Sudoyo A, Stiyohadi B, Syam A. Buku Ajar Ilmu Penyakit Dalam Jilid 1. 4th ed. Jakarta: Interna Publishing; 2014. 1132-53 p.

12. Mahasurya IGAD. Gambaran Pemeriksaan Serologi IgM-IgG Antidengue Pada Pasien Terinfeksi Virus Dengue di Rumah Sakit Surya Husada Denpasar Baliperiode Desember 2013 Sampai Mei 2014. Universitas Udayana; 2014. 